\title{
Government Expenditures and Macroeconomic Indicators in
} Nigeria

\author{
Emmanuel Uzoma Makwe (Ph.D) $)^{1} \quad$ Akeeb Olushola Oladele ${ }^{2}$ \\ 1.Department of Economics, Faculty of Social Sciences, School of Graduate Studies, University of Port \\ Harcourt, PO box 488, Uniport Nipost, Choba, Port Harcourt, Rivers State, Nigeria \\ 2.Department of Economics, Faculty of Social Sciences, School of Graduate Studies, University of Port Harcourt
}

\begin{abstract}
This study examined the impact of government expenditure on selected macroeconomic variables from 1983 to 2017. Secondary data sourced from Central Bank of Nigeria Statistical Bulletin of various issues was used. The researcher used Gross Domestic Products and Unemployment Rate as the proxy of the dependent variables while government expenditures on education; health; and agriculture constituted the proxies for the independent variable. The analytical technique used was regression analysis of the ordinary least square (OLS) based on the Auto Regressive Distributed Lag used to analyze the data. The result revealed that government expenditure in the agricultural sector has negative and insignificant relationship with gross domestic product while government expenditure in the educational and health sectors have positive and significant relationship with Gross Domestic Products. Government expenditure in agriculture has a negative relationship with Unemployment Rate while government expenditure in education and health sectors has positive and significant relationship with Unemployment Rate. Based on our findings therefore, the paper recommended that governments direct financial expenditures on agriculture should be reduced gradually until it is eliminated; the government should sustain her expenditures in the other sectors but must work on the root causes of what happens in the educational system of the country.
\end{abstract}

Keywords: Government Expenditures, Macroeconomic Variables, Gross Domestic Products, Unemployment Rate, Agricultural Sector, Educational Sector, Health Sector.

DOI: $10.7176 / \mathrm{JESD} / 10-14-06$

Publication date:July $31^{\text {st }} 2020$

\section{Introduction}

Government expenditures play significant roles in the effective functioning of all economies. It refers to expenses incurred by government in the maintenance of herself and provision of public goods and services required to promote economic growth and improve the welfare of people in the society. Government expenditures are generally categorized into expenditures on administration, defence, internal securities, health, education, agriculture, construction, etc. And has both capital and recurrent components. Capital expenditure pertains to the summative amount used up in acquiring fixed (productive) assets whose value spans beyond one accounting or fiscal year, likewise incurred expenditure on upgrade/improvement of existing fixed assets like roads, lands, building machines and equipment, etc., together with intangible assets. Expenditure on research as well counts as part of this component of government expenditure. Capital expenditure is generally thought of as expenditure which produces future benefits, seeing that lags could occur between the incur time and when it takes effect in the economy. Recurrent expenditure contrarily refers to spending on purchase of goods and services, wages and earnings, operations along with current grants and subsidies (typically categorized as transfer payment).

The association between government spending and economic growth has been treated extensively in literature both theoretically and empirically. The theoretical foundation of this relationship has been long standing going back to Wagner (1883), to Keynes (1936), Peacock and Wiseman (1961), and later to Musgrave (1969). The causality concerning public expenditure and economic growth brought about two schools of thought. The first is that public expenditure is an outcome of economic growth as suggested by Wagner (1883) while the other is posited by Keynes (1936) which is of the opinion that the government makes use of public expenditure as a tool to reverse economic recessions through borrowing from the private sector and then through various spending programmes return back to them, thus, economic growth arises out of public expenditure.

Maku (2009) stresses that the form and pattern of growth when it comes to economic output is determine by the structure of public expenditure. According to Anyanwu (1997), the question of how expenditure is or should be patterned has been addressed by public expenditure. The role played by expenditure in reducing regional differences, creation of infrastructure of economic growth, developing social overheads in the form of transport and communication facilities, industries, growth of capital goods, education and training, research and development, basic and key industries etc. this view was backed by Akpan (2005), Todaro and Smith (2006) and likewise Appah (2010) when they contended that infrastructure investment and productive activities as a result of public expenditure should add positively to development. On this premise therefore, germane questions like: what is the nature of relationship between government expenditure and macroeconomic variables in Nigeria needs to be 
addressed.

\subsection{Statement of the Problem}

For a country with vast resource having a preponderance of her populace in abject poverty conditions, whose infrastructure is in ruining, whose education, health and other growth-promoting and welfare-enhancing institutions are on the edge of collapse, whose roads are now considered death traps because of their awful states, and whose power sector is in a state of decline, it is expected that recurrent expenditure will be dominated by the share of capital expenditure in total expenditure, considering its function in economic growth and human development, but this has not been the case for Nigeria.

In Nigeria, government spending has been on the upside primarily because of the enormous receipts from production and sales of crude oil, and the surge in demand for public (utilities) goods like roads, power, communication, education and health. Furthermore, there is a growing need to provide both internal and external security for the people and the nation. Unfortunately, translating this growing government expenditure into meaningful growth and development has been quite slow, as Nigeria ranks among the poorest countries in the world. In addition, the number of Nigerians reeling in poverty in on the rise, while more than half the population live on less than US $\$ 2$ per day. Combined with this, are dilapidated infrastructures (particularly roads and power supply) that has resulted in the folding of many industries, with high levels of joblessness and abandoned elephant projects. Also, macroeconomic indicators like balance of payments, inflation rate, import obligations, national savings and exchange rates reveal that Nigeria has not thrived in the last couple of years. Another challenge has been to direct public expenditure in an effective matter into those areas of the economy which would yield optimal results in terms of growth, consumption and distribution. However, regardless of the ample volumes of empirical research conducted in Nigeria which are aimed at pinpointing the significance of public expenditure on macroeconomic variables resulting in differing outcomes, particularly with contributors' haven weaken the relationship between the specific components of public expenditure and macroeconomic variables this thus creates a gap in literature. In an attempt to fill this existing gap that has been identified in literature the researchers intend to study government capital expenditure and macroeconomic variables in Nigeria.

\subsection{Objectives of the Study}

The general objective of this study is to investigate government total expenditure and its effects on the macroeconomic variables in Nigeria using some key sectors of the Nigerian economy. However, the specific objectives include;

i. Examine the relationship between government expenditure in education and gross domestic products in Nigeria.

ii. Assess the relationship between government expenditure in health and gross domestic products in Nigeria.

iii. Determine the relationship between government expenditure in agriculture and gross domestic products in Nigeria.

iv. Examine the relationship between government expenditure in education and unemployment rate in Nigeria.

v. Assess the relationship between government expenditure in health and unemployment rate in Nigeria.

vi. Examine the relationship between government expenditure in agriculture and unemployment rate in Nigeria.

\subsection{Research Hypotheses}

Ho1: There is no significant relationship between government expenditure in education and gross domestic products in Nigeria.

Ho2: There is no significant relationship between government expenditure in health and gross domestic products in Nigeria.

Ho3: There is no significant relationship between government expenditure in agriculture and gross domestic products in Nigeria.

Ho4: There is no significant relationship between government expenditure in education and unemployment rate in Nigeria

Hos: There is no significant relationship between government expenditure in health and unemployment rate in Nigeria

Ho6: There is no significant relationship between government expenditure in agriculture and unemployment rate in Nigeria 


\subsection{Literature Review}

\subsection{Conceptual Review}

\subsubsection{Government Expenditure in Nigeria}

In Nigeria, different political regimes have assumed a significant role in the provision of public (utilities) services like roads, electricity, telecommunication, education and health, likewise enhancing the financial stand of the whole Country. For the most part, government spending in Nigeria can be arranged into two components: recurrent expenditure and capital expenditure. Recurrent expenditure on goods and services are spending that does not amount to the creation or procurement of fixed assets (either new or second-hand). It involves for the most part spending on wages, earnings and supplements, acquisition of products and services and utilization on fixed capital (depreciation) (National Housing Assistance Data Dictionary). The trend of public spending in Nigeria throughout the years, however, has been conflicting and can be divided into two phases: pre-liberalization period (before 1986) which was characterized by a military administration and post-liberalization era (after 1986) made up partly of the military regime which gave way to a civilian regime from 1999 to date. It should be noted that 1986 mark the introduction of the Structural Adjustment Program (SAP) in Nigeria. Government expenditure did not contribute much to the growth of the economy in the 1960s owing to the intense civil war. In the 1970s under the military regime, some sectors started benefiting from the government. For example, rural farmers benefited from the state spending along with the poor sections of the population in the form of subsidized water supply health services, electricity etc. During this period the growth rate on average stood at 2.6\%. From 1980 to 1986, fiscal policy was geared mainly at generating revenue through increased tax efforts and the control of public spending. But there were unsuccessful efforts to sustain the revenue collection with a significant drop in total government expenditure.

With the introduction of the structural adjustment program which marked the post-liberalization era, strict measures were put in place to curb government spending: reduction in wage bills, reduction in government subsidies, limiting or delaying investment projects, privatization/commercialization with growth increasing to $8.3 \%$. However, the period 1990-1995 saw the regime's efforts to combat inflation hence large budgetary deficits were avoided which made government expenditure more cost-effective consistent with the nations resources. The latter 1990 s to 2000 s witnessed a restrictive fiscal policy with the introduction of a modified value added tax and also subsidizing local industries. The levels of capital expenditure were higher within the pre-liberalization era (1973-1984) than the post-liberalization era. This could be credited somewhat to the degree of corruption in the nation in particularly as Nigeria was once rated as the most degenerate country inside the post-advancement era.

Public spending is utilized for allocation, adjustment and circulation of resources (Musgrave and Musgrave 1989). The assignment work gets fundamental in order to give both private and specifically, social products in suitable blend in with accessible assets. Because of exceptional attributes of products (spill - over, externalities, non-excludability/joint utilization, non-contentions) they won't be given by any stretch of the imagination, or where they are delivered the yield will be lacking and ludicrously exorbitant whenever left in the hands of private people, the administration mediates by utilizing the instruments of government spending and other financial policy devices.

Omoruyi (1998) opine that public expenditure stabilizes through maintaining a high work rate, have a practical level of price stability, keep up a reasonable pace of financial growth, with allowance for impact on trade and on the balance of payment. Along these lines the stabilization function is concerned about the achievement by the national economy of full employment and capital use at stable price, a good balance of intervention performance and a satisfactory rate of growth in per capita income over a period of time.

Nigeria's federal expenditure can be classed into government functions like administration, economic service, social and community service and transfer. Expenditure with respect to administration involves general administration, security, internal security and national assembly. Social and community services incorporate those for education, health and other social and community services. Agriculture, transport and telecommunication, construction and other financial services falls under economic service expenditure. Government transfer integrates servicing of public debt, pension and gratuities, contingencies/subventions, and so on. (CBN Statistical Bulletin, 2018). Aside government transfer, different classifications or classes of public spending have capital and recurrent components.

Nigeria's federal government's capital and recurrent expenditure inclined upwards in a large portion of the 1980 to 2011 period, with recurrent expenditure rising quicker than capital expenditure. Data obtained from the CBN Statistical Bulletin (2018) uncovers that recurrent expenditure surpassed capital expenditure almost seventytwo percent of the periods. In particular, the recurrent expenditure in the 1984-85, 87-95 and 2000-2011 periods was more than the capital expenditure in every year. The margin among recurrent and capital spending turned out to be wide start from year 2000, soon after the nation came back to democratic governance on May 29, 2009, a sign that the nation's democratic government has would in general support recurrent spending more than capital spending. This could be ascribed to different elements, for instance, development in the size of the legislature as the quantity of workers on government payroll, just as wages and salaries of workers in certain divisions of the economy has cosmically expanded, similarly as government's acquisition of goods and services and grants likewise 
soar. Up to this point, when the administration needed to pull back subsidies partially from some oil based commodities, the sum spent on subsidies as guaranteed by the administration was very faltering, however it was later uncovered that some fraudulent independent marketers of oil based commodity in conspiracy with some top political office holders were answerable for the gigantic spending that went into subsidies. Then again, the capital spending diminished about $60 \%$ in the $1980-84$ periods. Meanwhile, from 1980 to 1983, capital use was more than the recurrent spending. Aside from 1986, and 1996-2000 periods, the government capital expenditure was lower compared with the recurrent spending.

From the 1980 - 1983 periods, the portion of capital spending surpassed that of recurrent spending. From 1984 to 1985 the portion of recurrent spending in total expenditure was more than the capital expenditure. From 1987 to 1995, the portion of recurrent spending reliably surpassed that of capital spending. From 1996 to 1999 capital expenditure surpassed that of recurrent expenditure. From 2000 to 2011, the portion of recurrent spending was more than that of capital spending. A glance at the capital and recurrent expenditure GDP ratios uncovers that from 1980 to 1983, the capital spending GDP ratio was more than the recurrent spending GDP ratio. From 19841985 and 1987 to 1995, the recurrent spending GDP ratio surpassed the capital spending GDP ratio. From 1996 to 1999, the capital spending GDP ratio surpassed the recurrent spending GDP ratio. From 2000 to 2011, the recurrent spending GDP ratio surpassed the capital expenditure GDP ratio. The circumstance was likewise the same between 2012 to 2018. Nonetheless regarding the aforementioned, it could be derived that the present state of Nigeria's economy could be somewhat connected to the pattern of spending of her legislature. Instinctively, for a developing country, capital expenditure (especially in capital projects or infrastructure) should establish noteworthy extent of her complete expenditure, to establish the foundation for economic development and feasible development; however, this has not been the situation in Nigeria. In any case, we are mindful so as not to bounce to the end, that the dominance of recurrent spending over capital expenditure has antagonistically influenced the country's economy, as this is absolutely an empirical issue.

\subsubsection{Concept of Gross Domestic Products}

A nation's GDP is the total value of all final goods and services produced for the market place during the year, within the nation's borders. Abbas, Akbar, Nasir, Ullah \& Naseem, (2011) observes, "A nation's GDP is calculated by adding together total consumer spending, total government spending, total business spending and the value of net exports". Gross Domestic Products is one of the essential indicators of a country's economic status or health. It is also used to gauge the living standard of a given country. Ayanwale, (2007) suggests that "Gross Domestic Products can be expressed in nominal or real terms. Nominal GDP mirrors the value of all the products and services which are produced in a country throughout a given period, using their price at the time of production. Real Gross Domestic Products similarly imitates the value of produced goods and services, but it utilizes constant consumer and producer price indices to eliminate the effects of rising price levels (inflation). Periods of real Gross Domestic Products growth are assumed to promote the welfare of people as economic growth makes it probable for average incomes to increase, which in turn translates to a greater extent of consumption. Periods of negative real Gross Domestic Product growth are associated with lower incomes, lower consumption and consequently a lower standard of living".

The estimation of Gross Domestic Products can adopt a number of approaches. Ekweogu (2013) asserts that "the production estimate hinges on the values using three different methods; the production estimate is dependent on the estimation of final output in the economy less the inputs used up in the production process, the expenditure estimate is depends on the estimation of total expenditure on goods with services, barring intermediate goods with services, produced domestically during a given period, the salary value quantifies the earnings earned by people and corporations directly from the production of outputs (goods and services). Further, Ekweogu (2013) infers that "Gross Domestic Products is estimated on a quarterly basis and if perfect data were available, the three approaches would generate equal estimates. Some of the benefits of Gross Domestic Products are and not limited to; Gross Domestic Products is considered the broadest indicator of economic output and growth, Real Gross Domestic Products considers inflation, making it likely for comparisons against other historical periods and that the Bureau of Economic Analysis issues its own analysis document with each GDP release, which is a great investor tool for analyzing figures and trends, and reading highpoints of the very lengthy full release".

\subsubsection{Concept of Unemployment}

The concept of Unemployment has received various definition and descriptions; this owing to the fact that human beings often view things from different perspectives. Unemployment is perceived as one of the most testing social problems currently facing Nigeria. In the last two decades and more recently with the global recession high levels of Unemployment have become an established feature of the Nigerian social and economic landscape, with young people aged 15 to 24 years among those most affected by Unemployment (Omankhanlem, 2011).

According to Salami (2013), Unemployment or joblessness, as described by the International Labour Organization (1982) occurs when people are without jobs and they have actively sought work within the past five weeks. The Unemployment rate is a ratio of the prevalence of Unemployment and it is determined as a rate by dividing the number of jobless people by all people at present in the labour force. The Newsweek (2011) revealed 
that in excess of 200 million individuals all around are out of work, a record high, as virtually two-thirds of developed economies and half of emerging nations are experiencing a slowdown in employment growth.

Dependence on jobs to make money to buy food and shelter was the beginning of Unemployment (Olayiwola \& Okodua, 2007). Because it has not always been acknowledged or measured systematically, there are limited historical records on Unemployment (Okodua, 2009). Arico (2003), opined that an individual is considered to be unemployed if such a person is eligible for work but does not have paid job. Josten (2006) maintained that an Unemployment situation is usually noted as mass-unemployment when the number of qualified manpower who are not employed or are unemployed is considerably high or out numbers that of those who are gainfully employed. Tripier (2007) perceived that the term Unemployment is used to refer in literal sense to all those without work, but however stated that this term (Unemployment) has come to have more specific meaning in contemporary realization of social and economic policy.

Pissarides (2000) conceptualized Unemployment simply as to be left without means of sustenance, without an opportunity to eat food and to have decent housing, it means to lose confidence in today and hope for tomorrow. To a layman, this description of Unemployment has gone a long way in providing a common and ordinary explanation on what Unemployment actually looks like. Parello (2010) views Unemployment as the number of people in the population who are willing and able to offer themselves for employment but could not be employed because of lack of vacancies for them. However, the most appropriate and self-explanatory definition of Unemployment is that offered by Moreno-Galbis (2012), who sees Unemployment as a social-economic situation in which persons who have no work and are able and willing to work and also actively seeking for work are unable to secure a gainful employment.

Moreno-Galbins (2012) also observed that there is considerable controversy concerning the number and nature of persons that should be classified as unemployed in a country at a particular point in line. Thus, MorenoGalbins (2012) argued that only those persons not at work for more than a specified minimum time period and who are able and willing to work and actively seeking work are generally considered as unemployed. According to Neto \& Silva (2013) the term unemployed is not applied to everyone who is not employed but to only those who have attained the legal working age and above and who are without job and are seeking for work.

The fact is that there is no reliable data on the exact figure of Unemployment in Nigeria, however, a very large population of the work age groups in Nigeria are unemployed. The International Labour Organization (2010) half-year report on the national Unemployment rate by the Federal office of statistics has indicated a high Unemployment rate among school leavers and uneducated people. The age between 15 and 24 years has the highest rate of $29.3 \%$, while the group between 45 and 59 years had $10.3 \%$ and the age of $65-70$ years has $16.7 \%$. This pattern was maintained when the rates were considered within the urban and rural sectors in Nigeria.

In a similar account, the National Directorate of Employment (NDE) (2013) stated that one out of every twelve Nigerians was unemployed in the urban sector, while one out of every six Nigerians was unemployed in the rural sector in Nigeria. Going by this NDE report, it seems right if one claims that over ten million Nigerian workforces are unemployed. Omankhanlen (2011) maintained that the most active population group in Nigeria is the most affected group by Unemployment. He claimed that $39.3 \%$ of the unemployed in Nigeria falls within the 15-19 years' age group.

Obviously Unemployment adversely influences Economic Growth and Development. This is on the grounds that less number of adolescents adds to the improvement of the economy. They just fill in as spillages to the economy and this is one of the serious issues confronting the Economic Development of any country. Joblessness rate in Nigeria was 5.1\% in 2010, it expanded to $6.0 \%$ and $10.6 \%$ in 2011 and 2012 individually. In the year 2013, joblessness rate dropped somewhat to $10.0 \%$ and dropped further to $7.8 \%$ and $9.0 \%$ in the years 2014 and 2015 individually. Joblessness rate in Nigeria anyway expanded to $13.4 \%$ in 2016 and by 2017 , it has ascended to $16.5 \%$. Joblessness Rate in Nigeria expanded to 18.80 percent in the second from last quarter of 2017 from 16.20 percent in the second quarter of 2017. Joblessness Rate in Nigeria arrived at the midpoint of 10.63 percent from 2006 until 2017, arriving at an untouched high of 19.70 percent in the final quarter of 2009 and a record low of 5.10 percent in the final quarter of 2010 (CBN, 2017).

\subsection{Empirical Review}

Some empirical work on the relationship between government expenditure and economic growth was extensively explored in this study.

Canning and Pedroni, (2004) conducted a study government expenditures and economic growth using a panel of countries over the period 1950 - 1992, by utilizing simple panel based tests. The results showed clear proof that majorly in the cases; infrastructure does prompt long run growth effects. The result additional demonstrated that telecommunication, electricity, generating capacity and good roads are provided at close to the growth maximizing level of average.

Bose, Haque and Osborne (2007) carried out a research on government capital expenditures and economic growth using a panel of 30 developing countries over the period 1970-1990, using ordinary least square regression. 
The experimental outcomes uncovered that the portion of government capital expenditure in (GDP) is decidedly and fundamentally related with economic growth, while the development impact of current spending is inconsequential. The outcome additionally uncovered that government investment in education and all out spending in training was the main expenses that remained fundamentally associated with growth all through the investigation.

Bagdigen and Cetintas (2004) conducted a study on Turkish public expenditure and economic growth over the period 1965-2000 using the co-integration and the Granger causality test. The result of the empirical analysis showed no causality in both directions, this revealed that neither Wanger's law nor Keynesian hypothesis is valid for the Turkish case.

Ando (2009) carried out an empirical study on government expenditures and economic growth using a panel data over the period 1995-2003 using the ordinary least square economic growth equation based on Feder model. The outcome of the investigation showed that defence expenditure impacted the economic growth positively.

Maku (2009) organized an empirical study on government expenditures and economic growth using a time series data for 1977-2006, and using classical least square, regression model and Durbin Watson Test for analysis. The result of the test showed that private and public investments have insignificant effects on economic growth.

Lecuwen and Foldvari (2007) conducted an empirical study on public expenditures and economic growth by applying a sample of Japan, Indonesia and India from 1890-2000 using Johansen co-integration test. The outcome revealed that in India and Indonesia the level of human capital is co-integrated with the level of aggregate income during the whole $20^{\text {th }}$ century. In Japan, the Hucasian approach was verified only for the first half of the century, while after 1950, there was a co-integration between growth rate of aggregate income and the level of human capital.

Yuk (2005) carried out a study of a time series analysis of government expenditures and economic growth in the United Kingdom for the period 1930 - 1993 using a trivariate VAR mode, multiple regression and Dickeyfuller tests. The empirical result supported the export-led growth and although the support for Wagner's law was sensitive to the choice of the sample period, there was evidence that gross domestic product (GDP) growth Granger-causes the share of government spending in GDP indirectly through export share of gross domestic product during the period.

Arpaia and Turrini (2008) conducted an empirical study on government expenditure and economic growth with a sample of EU-15 countries over the period 1970-2000, using panel unit root tests and co-integration analysis. The result of the empirical analysis showed that the estimation method matters substantially for the measurement of the relation between government expenditure and potential output.

Yasin (2008) organized an empirical analysis on government expenditures and economic growth with a panel data from 26 sub-Saharan African countries for the period 1987-1997 using fixed-effects and random effects estimation technique. The empirical results from both estimation techniques indicated that government spending on capital formation trade openness and the private investment spending all have positive and significant effects on economic growth.

Colombire (2009) conducted a study on government expenditures and economic growth with a time series data set using the ordinary least square regression for the period 1965-2005 in Switzerland. The result of the empirical analysis provided strong evidence that government outlays for transport infrastructures, justice and general government are vital for output growth. Whereas, the empirical evidence for a growth effect of education is weak and therefore a reversed causation effect could be ascertained. Also the empirical result showed that the evidence concerning the growth effect of social justice and health care were not clear cut.

\subsection{Research Methodology} 3.1 Research Design

Research design describes the method the researcher adopted to prosecute the research task. Thus, in this study, a quasi-experimental design was adopted. This would allow for the evaluation of the effects of independent variables on the dependent variable.

\subsection{Data Collection Method and Source}

The data used for this study were obtained from the Central Bank of Nigeria, Statistical Bulletin and World Bank Data Reports covering the period $1980-2017$.

\subsection{Techniques of Data Analysis}

The Ordinary Least Square regression, Augmented Dickey-Fuller, Co-integration, Granger Causality, and Error Correction Mechanism (ECM) were relied upon to analyse the data collected, by specifically conducting a shortrun analysis based on:

i. Apriori test to check whether the signs and sizes of the variables used conforms with the apriori expectations in the economy. 
ii. Statistical tests will be conducted using the t-tests and f-test. The t-tests tests the individual significance of the variables used while the f-test, tests the overall significance of the variables used in the model.

iii. Econometric tests: (Durbin-Watson (DW) statistics was conducted to determine if there was autocorrelation among the error terms of the variables used as this will affect the usage of the data results.

\subsubsection{Pre-Estimation Test Analysis}

1. Descriptive Statistics: This contains the skewness, kurtosis and normality tests. At a glance, the descriptive statistics table tells the researcher the type and shape of data he is working with.

1. Unit Root (Stationarity Test: As pointed out earlier, the researcher shall test for stationarity of the time series using the Augmented Dickey-Fuller Test (ADF) if the short-run analysis shows a spurious regression result. The null hypotheses are rejected, but if the t-values of the ADF are greater than the critical values, otherwise, the null hypothesis is accepted.

The test Kwaitkowski, Philips, Schemidt, and Shin: KPSS (1992) approach to stationary test was employed to examine whether the mean, variance and the autocovariance of each of the series do not change over time. The null hypothesis of the stationarity is tested against the alternative hypothesis of no stationarity. The model for the stionarity test is given as follows:

$$
\Delta X=a 0+a i X t-1+\sum_{i=1}^{h} b i \Delta X t-1+\grave{U}
$$

Where $\mathrm{X}_{\mathrm{i}}=$ Economic time series under investigation; $\mathrm{a}_{\mathrm{i}}$ and $\mathrm{b}_{\mathrm{i}}=$ parameter estimates; $\mathrm{h}=$ lag length; $\Delta$ = first difference operator and $\dot{U}_{\mathrm{i}}=$ random disturbance term.

3.3.2 Co-integration Analysis Test: The researcher shall conduct a long-run analysis using Johansen cointegration analysis due to the number of variables used in the model as compared to Engel-Granger Cointegration Analysis that supports simple and single linear regression model. The Johansen co-integration analysis has unrestricted intercept and no trends in vector auto-regression (VAR). The general form of cointegration procedure is given as follows:

$$
\text { Mt }=\varphi t M t-1+\cdots \varphi p M t-p+\beta R t+\grave{U} t
$$

Where $\mathrm{M}_{\mathrm{t}}=$ Economic time series under investigation; $\mathrm{TM}_{\mathrm{t}-1}$ and $\mathrm{PM}_{\mathrm{t}-\mathrm{p}}=$ cointegrating equations estimates; $\boldsymbol{\varphi}=$ first difference operator and $\grave{U}_{\mathrm{i}}=$ random disturbance term.

3.3.3 Error Correction Mechanism: (ECM) shall be used in correcting the short-term disequilibrium of the longrun analysis. This is the final point of the second order test. The interpretation of the hypotheses shall be based on the results of the ECM. The ECM is given mathematically as follows:

$$
\mathrm{Z}_{\mathrm{t}}=\alpha i+\sum_{i=1}^{k} W i=1+\sum_{i=1}^{k} V i=1 \ldots+U i
$$

Where $Z_{\mathrm{t}}=$ Economic time series under investigation; $\mathrm{W}_{\mathrm{i}}$ and $\mathrm{V}_{\mathrm{i}}=$ parameter estimates; $\mathrm{t}=$ lag length; and $\grave{U}_{\mathrm{i}}=$ random disturbance term.

\subsubsection{Post-Estimation Tests}

The analysis used includes the following diagnostic tests to satisfy the assumptions of OLS analysis.

i. Serial autocorrelation: for the residuals tests for the presence of serial autocorrelation among the independent variables.

ii. Heteroscedasticity: Test was conducted to determine whether the variance of the regression is constant or not over time. If the variance is not constant, there will be high standard error resulting to poor analytical use of the result. To accept the presence of Heteroscedasticity probability of F-test must be less or equal to the confidence interval. In this case, $95 \%$ confidence interval (or $5 \%$ level of significance) is used. For the purpose of this analysis, the researcher shall use the White heteroscedasticity test. This test is based on the null hypothesis that there is no heteroscedaticity. The null hypothesis is rejected if the calculated value of $\mathrm{F}$ is greater than the table value.

iii. CUSUM Test: The aim of the test is to see whether the models are properly specified or not. This test appears in a graphical form, unlike the Ramsey Reset Test. However, both tests are used to check if the model is properly specified or not.

\subsection{Model Specifications}

The analysis will be based on multiple linear regression models using the Autoregressive Distributed Lag (ARDL). Therefore, the models used for the purpose of this study are stated below:

\section{Model I}

Mathematically:

$\mathrm{GDP}_{\mathrm{t}}=\mathrm{f}\left(\mathrm{GAGR}_{\mathrm{t}}, \mathrm{GEDU}_{\mathrm{t}}, \mathrm{GEEH}_{\mathrm{t}}\right)$

Functionally:

$\mathrm{GDP}_{\mathrm{t}}=\mathrm{b}_{0}+\mathrm{b}_{1} \mathrm{GAGR}_{\mathrm{t}}+\mathrm{b}_{2} \mathrm{GEDU}_{\mathrm{t}}+\mathrm{b}_{3} \mathrm{GEEH}_{\mathrm{t}}+\mathrm{U}_{\mathrm{i}}$

Model II

$\mathrm{UNEM}_{\mathrm{t}}=\mathrm{f}\left(\mathrm{GAGR}_{\mathrm{t}}, \mathrm{GEDU}_{\mathrm{t}}, \mathrm{GEEH}_{\mathrm{t}}\right)$ 
Functionally:

$\mathrm{UNEM}_{\mathrm{t}}=\mathrm{b}_{0}-\mathrm{b}_{1} \mathrm{GAGR}_{\mathrm{t}}-\mathrm{b}_{2} \mathrm{GEDU}_{\mathrm{t}}-\mathrm{b}_{3} \mathrm{GEEH}_{\mathrm{t}}+\mathrm{U}_{\mathrm{i}}$

Where:

$\mathrm{GDP}_{\mathrm{t}}=$ Gross Domestic Product.

$\mathrm{UNEM}_{\mathrm{t}}=$ Unemployment Rate

GAGR $=$ Government total expenditure on agriculture

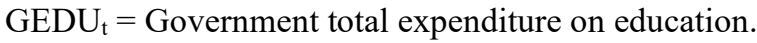

GEEH $=$ Government total expenditure on health

$\mathrm{U}_{\mathrm{i}}=$ Stochastic Term or error term (used to cover all the other variables that affect GDP but were not included in the model). $\mathrm{b}_{0}=$ Intercept

$\mathrm{b}_{1}-\mathrm{b}_{3}=$ coefficients of the variables

On the apriori expectations, the study expects:

$b_{1}>0 . b_{2}>0, b_{3}>0$.

\subsection{Justifications for the use of the Variables in the Study}

GDP: This is the gross domestic product. The GDP is the most appropriate method of measuring the performance of the economy. In other to determine the importance of the government total sectoral expenditure on the economy, the GDP is used.

UNEM: Unemployment rate allows for the measure of economic development. For the purpose of this study, the unemployment rate is used to capture the economic development aspect of the research work.

Independent Variables:

Government total expenditures (Agriculture, Health and Education): The researcher used government's total expenditures on agriculture, health and education as the key institutions that directly affect the human capital development of the people.

Eview 10.0 software was used for this purpose.

\subsection{Data Analysis and Results}

The table in the appendix show the trends of the variables over the period of study. Starting with the GDP, the data shows that it increased from N640m in 1980 to N1.6b the following year. In 1983, it decreased to N970m when the country slid into recession for the first time in history during the regime of General Muhammadu Buhari. After a period of recession, the GDP bounced back to growth. By 2003, the GDP was N104b and this continued to increase till 2014 when it peaked at N514b. Thereafter, the country slid into recession the second time during the administration of President Muhammadu Buhari. Only recently had the GDP showed positive signs.

The unemployment rate has been fluctuating over the period. However, the trend will be analysed by separating the periods of single digit unemployment rate and the period of double digit unemployment rate. From 1980 to 1998, could be categorised as a single digit unemployment era. From 1999 - 2017, double digit unemployment era ruled. The fluctuations are due to poor economic policies from the government. Others were from the dwindling oil prices and altogether decreased world aggregate demand. Series of job cuts and loss of businesses resulted to the worsening unemployment situation.

The government total expenditure on agriculture, education and health has been low by all standards. From 1980 total agricultural expenditure increased marginally from N2.8b to N12.4b. By 1986, it was N31.06b. The increment in agricultural expenditure continued till 1999 (N66.23b) before crashing down to N21.1b. This could have been as a result of the transition of government. However, by 2007, it was high at N126b; decreased to N96b in 2012 and then increased N115b by 2015 .

For the educational sector, the total government expenditure has also fluctuated over the period. For the first 5 years $(1980$ - 1985), the expenditure was higher than from $1986-2004$ in dollar terms. This is a clear indication that the educational sector has not been made a priority by the successive governments over the period.

However, the health sector has seen substantial total government expenditure. It rose from N302m in 1980 to 360 by 1986. This continued over the years; 1997 (N29b), 2001 (N44b), etc. Although, the increment has not been consistent over the years, majority of the years has shown higher figures than lower figures.

\subsection{Descriptive Statistics}

The descriptive statistics shows, at a glance, the nature of the time series data used. The analysis shows that in model I, the GAGR and GEDU are normally distributed. In model II, the normally distributed variables are GAGR, GEDU and UNEM. This is as show in the table below; 


\section{Model I}

\begin{tabular}{|c|c|c|c|c|}
\hline & GDP & GAGR & GEDU & GEEH \\
\hline Mean & $1.76 \mathrm{E}+11$ & 67.05974 & $1.43 \mathrm{E}+09$ & 58361.42 \\
\hline Median & $8.47 \mathrm{E}+10$ & 60.90000 & $9.24 \mathrm{E}+08$ & 17181.10 \\
\hline Maximum & $5.68 \mathrm{E}+11$ & 171.4000 & $4.67 \mathrm{E}+09$ & 447948.2 \\
\hline Minimum & $2.78 \mathrm{E}+10$ & 2.800000 & $1.14 \mathrm{E}+08$ & 190.2000 \\
\hline Std. Dev. & $1.64 \mathrm{E}+11$ & 43.47394 & $1.32 \mathrm{E}+09$ & 90191.00 \\
\hline Skewness & 1.028724 & 0.569848 & 0.934154 & 2.540541 \\
\hline Kurtosis & 2.628050 & 2.634448 & 2.661379 & 10.64705 \\
\hline Jarque-Bera & 6.921450 & 2.268180 & 5.708298 & 133.4668 \\
\hline Probability & 0.031407 & 0.321715 & 0.057605 & 0.000000 \\
\hline Sum & $6.68 \mathrm{E}+12$ & 2548.270 & $5.42 \mathrm{E}+10$ & 2217734 . \\
\hline Sum Sq. Dev. & $9.91 E+23$ & 69929.37 & $6.45 E+19$ & $3.01 \mathrm{E}+11$ \\
\hline Observations & 38 & 38 & 38 & 38 \\
\hline \multicolumn{5}{|l|}{ Model II } \\
\hline & GAGR & GEDU & GEEH & UNEM \\
\hline Mean & 67.05974 & $1.43 \mathrm{E}+09$ & 58361.42 & 10.13684 \\
\hline Median & 60.90000 & $9.24 \mathrm{E}+08$ & 17181.10 & 9.400000 \\
\hline Maximum & 171.4000 & $4.67 E+09$ & 447948.2 & 21.10000 \\
\hline Minimum & 2.800000 & $1.14 \mathrm{E}+08$ & 190.2000 & 1.900000 \\
\hline Std. Dev. & 43.47394 & $1.32 \mathrm{E}+09$ & 90191.00 & 6.161231 \\
\hline Skewness & 0.569848 & 0.934154 & 2.540541 & 0.207253 \\
\hline Kurtosis & 2.634448 & 2.661379 & 10.64705 & 1.473530 \\
\hline Jarque-Bera & 2.268180 & 5.708298 & 133.4668 & 3.961384 \\
\hline Probability & 0.321715 & 0.057605 & 0.000000 & 0.137974 \\
\hline Sum & 2548.270 & $5.42 \mathrm{E}+10$ & 2217734. & 385.2000 \\
\hline Sum Sq. Dev. & 69929.37 & $6.45 \mathrm{E}+19$ & $3.01 \mathrm{E}+11$ & 1404.548 \\
\hline Observations & 38 & 38 & 38 & 38 \\
\hline
\end{tabular}

Source: Eviews analysis

\subsection{Unit Root Tests}

The unit root tests help to determine the random work of the variables. It shows the researcher whether the data he is dealing with are stationary at levels, first or second differences or not at all. To determine this, the Augmented Dickey Fuller test is used. This also helped to determine the choice of test of cointegration (bounds test or Johansen). Conducting the ADF analysis, the researcher discovered that the variables are stationary at first difference as none in both models were found to have a stationary value at levels. This necessitated the use of Bounds Test for Cointegration to determine whether there is long term relationship among the variables used.

\section{Model I}

\begin{tabular}{|l|l|l|}
\hline Variables & Probability & Comments \\
\hline GEEH(-1) & 0.0000 & $\mathrm{I}(0)$ \\
\hline GEDU(-1) & 0.0002 & $\mathrm{I}(0)$ \\
\hline GDP(-1) & 0.0009 & $\mathrm{I}(0)$ \\
\hline GAGR & 0.0000 & $\mathrm{I}(0)$ \\
\hline
\end{tabular}

Source: Eviews analysis

Model II

\begin{tabular}{|l|l|l|}
\hline Variables & Probability & Comments \\
\hline GEEH(-1) & 0.0000 & $\mathrm{I}(0)$ \\
\hline GEDU(-1) & 0.0002 & $\mathrm{I}(0)$ \\
\hline UNEM(-1) & 0.0000 & $\mathrm{I}(0)$ \\
\hline GAGR & 0.0000 & $\mathrm{I}(0)$ \\
\hline
\end{tabular}




\subsection{Bounds Tests for co-integration}

Having analysed the unit root tests and discovered that the variables are stationary at first difference, not at levels, the use of bounds test to test for the long term relationship is used. Below, the bounds tests show that there is no long terms relationship between the variables as shown by the F statistics in the table.

\section{Model I}

F-Bounds Test

Null Hypothesis: No levels relationship

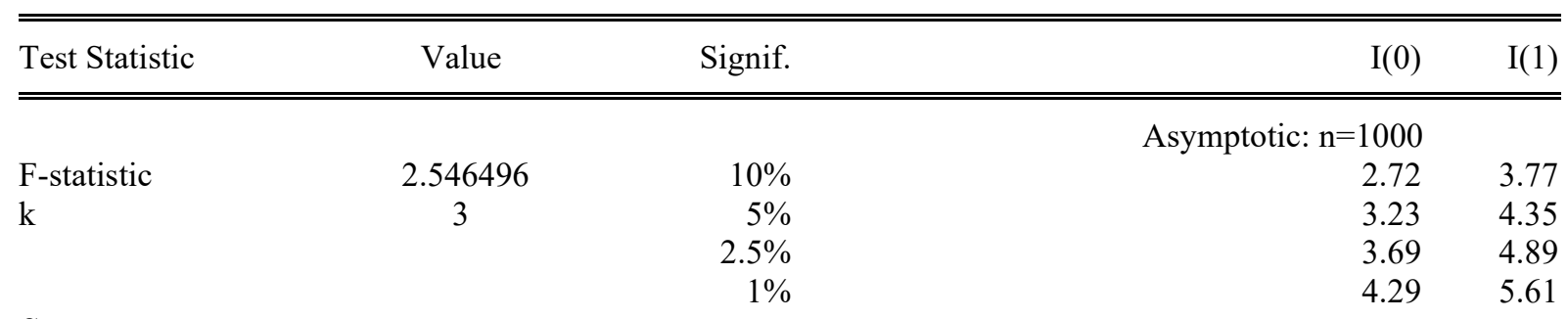

Source: eviews

\section{Model II}

F-Bounds Test

Null Hypothesis: No levels relationship

\begin{tabular}{lcccr}
\hline \hline Test Statistic & Value & Signif. & $\mathrm{I}(0)$ & $\mathrm{I}(1)$ \\
\hline \hline & & \multicolumn{3}{c}{ Asymptotic: } \\
F-statistic & & \multicolumn{3}{c}{$\mathrm{n}=1000$} \\
$\mathrm{k}$ & 2.272752 & $10 \%$ & 2.72 & 3.77 \\
& 3 & $5 \%$ & 3.23 & 4.35 \\
& & $2.5 \%$ & 3.69 & 4.89 \\
Sour & & $1 \%$ & 4.29 & 5.61
\end{tabular}

Source: Eviews

\subsection{Short Run Analysis}

The bounds test for co-integration show that there is no long term relationship among the variables used. The absence of the long term relationship limits the analysis to the short term. Below shows the short terms result analysis of the models.

\section{Model I}

Dependent Variable: D(GDP(-1))

Method: Least Squares

Date: 12/04/19 Time: 14:52

Sample (adjusted): 19832017

Included observations: 35 after adjustments

\begin{tabular}{|c|c|c|c|c|}
\hline Variable & Coefficient & Std. Error & t-Statistic & Prob. \\
\hline $\mathrm{C}$ & $5.39 \mathrm{E}+09$ & $4.30 \mathrm{E}+09$ & 1.253665 & 0.2203 \\
\hline $\mathrm{D}(\operatorname{GAGR}(-1))$ & $3.30 \mathrm{E}+08$ & $2.09 \mathrm{E}+08$ & 1.581011 & 0.1251 \\
\hline $\mathrm{D}(\mathrm{GAGR}(-2))$ & -3562148 & $2.04 \mathrm{E}+08$ & -0.017477 & 0.9862 \\
\hline $\mathrm{D}(\operatorname{GEDU}(-1))$ & 14.86724 & 8.870480 & 1.676035 & 0.1049 \\
\hline $\mathrm{D}(\operatorname{GEDU}(-2))$ & 53.00880 & 8.659872 & 6.121199 & 0.0000 \\
\hline $\mathrm{D}(\operatorname{GEEH}(-1))$ & -24283.91 & 55080.37 & -0.440881 & 0.6627 \\
\hline $\mathrm{D}(\mathrm{GEEH}(-2))$ & 20009.84 & 55548.80 & 0.360221 & 0.7214 \\
\hline R-squared & 0.634156 & Mean dependent var & & $6.86 \mathrm{E}+09$ \\
\hline Adjusted R-squared & 0.555761 & S.D. dependent var & & $3.68 \mathrm{E}+10$ \\
\hline S.E. of regression & $2.45 \mathrm{E}+10$ & Akaike info criterion & & 50.86124 \\
\hline Sum squared resid & $1.69 \mathrm{E}+22$ & Schwarz criterion & & 51.17231 \\
\hline Log likelihood & -883.0717 & Hannan-Quinn criter. & & 50.96862 \\
\hline F-statistic & 8.089220 & Durbin-Watson stat & & 1.611783 \\
\hline Prob(F-statistic) & 0.000040 & & & \\
\hline
\end{tabular}

Source: Eviews 


\section{Model II}

Dependent Variable: D(UNEM(-1))

Method: Least Squares

Date: 12/04/19 Time: 15:23

Sample (adjusted): 19822017

Included observations: 36 after adjustments

\begin{tabular}{|c|c|c|c|c|}
\hline Variable & Coefficient & Std. Error & t-Statistic & Prob. \\
\hline $\mathrm{C}$ & 0.412568 & 0.516320 & 0.799054 & 0.4302 \\
\hline $\mathrm{D}(\mathrm{GAGR}(-1))$ & -0.025774 & 0.024780 & -1.040085 & 0.3061 \\
\hline $\mathrm{D}(\operatorname{GEDU}(-1))$ & $2.09 \mathrm{E}-10$ & $1.02 \mathrm{E}-09$ & 0.205793 & 0.8383 \\
\hline $\mathrm{D}(\operatorname{GEEH}(-1))$ & $1.54 \mathrm{E}-08$ & $6.82 \mathrm{E}-06$ & 0.002255 & 0.9982 \\
\hline R-squared & 0.037850 & Mean dependent var & & 0.322222 \\
\hline Adjusted R-squared & -0.052352 & S.D. dependent var & & 2.970340 \\
\hline S.E. of regression & 3.047099 & Akaike info criterion & & 5.170696 \\
\hline Sum squared resid & 297.1141 & Schwarz criterion & & 5.346643 \\
\hline Log likelihood & -89.07254 & Hannan-Quinn criter. & & 5.232107 \\
\hline F-statistic & 0.419615 & Durbin-Watson stat & & 1.998716 \\
\hline Prob(F-statistic) & 0.740156 & & & \\
\hline
\end{tabular}

Source: Eviews

For model II, the analysis shows that the coefficient of determination is 0.035 , which implies that only $4 \%$ of the changes in the dependent variable is explained by the changes in the independent variables. The model is not statistically significant as shown by the f-stat.

The model II shows that the R-square is 0.037 . This means that the coefficient of determination is merely $4 \%$. Therefore, only $4 \%$ of the changes in the dependent variable is explained by the changes in the independent variables. The f-value shows that the model is not statistically significant when taken together.

\subsection{Serial Correlation}

The tests are used here to determine if there is a serial autocorrelation among the independent variables or not. Below, the tables for models I and II show there is no reason to reject the null hypotheses of no serial correlation based on the prob value of 0.6249 and 0.9749 respectively.

\section{Model I}

Breusch-Godfrey Serial Correlation LM Test:

\begin{tabular}{|c|c|c|c|}
\hline F-statistic & 0.478716 & Prob. F(2,26) & 0.6249 \\
\hline Obs*R-squared & 1.243076 & Prob. Chi-Square(2) & 0.5371 \\
\hline
\end{tabular}

Source: Eviews

\section{Model II}

Breusch-Godfrey Serial Correlation LM Test:

\begin{tabular}{|c|c|c|c|}
\hline F-statistic & 0.001002 & Prob. F(1,31) & 0.9749 \\
\hline Obs*R-squared & 0.001164 & Prob. Chi-Square(1) & 0.9728 \\
\hline
\end{tabular}

Source: Eviews

\section{Heteroskedasticity Test}

The test of constant variance is carried out using the heteroskedasticity test. It enables the researcher to observe how constant the variance. Additionally, the standard deviation can also be determined from this. In all, the models show that there is constant variance over the period. This is also good. 


\section{Model I}

Heteroskedasticity Test: Breusch-Pagan-Godfrey

\begin{tabular}{llll}
\hline \hline F-statistic & 0.992726 & Prob. F(6,28) & 0.4493 \\
Obs*R-squared & 6.139425 & Prob. Chi-Square(6) & 0.4078 \\
Scaled explained SS & 8.805628 & Prob. Chi-Square(6) & 0.1848 \\
\hline
\end{tabular}

Source: Eviews

\section{Model II}

Heteroskedasticity Test: Breusch-Pagan-Godfrey

\begin{tabular}{lllr}
\hline \hline F-statistic & 0.099633 & Prob. F(3,32) & 0.9596 \\
Obs*R-squared & 0.333150 & Prob. Chi-Square(3) & 0.9537 \\
Scaled explained SS & 1.811669 & Prob. Chi-Square(3) & 0.6124 \\
\hline \hline
\end{tabular}

\section{Source: Eviews}

\section{CUSUM Tests}

CUSUM Squared tests are used to check for model misspecifications. Here, the rule of thumb states that if the graph line lies within the critical values, the model is well specified. For our models, the CUSUM tests show that they are well specified.

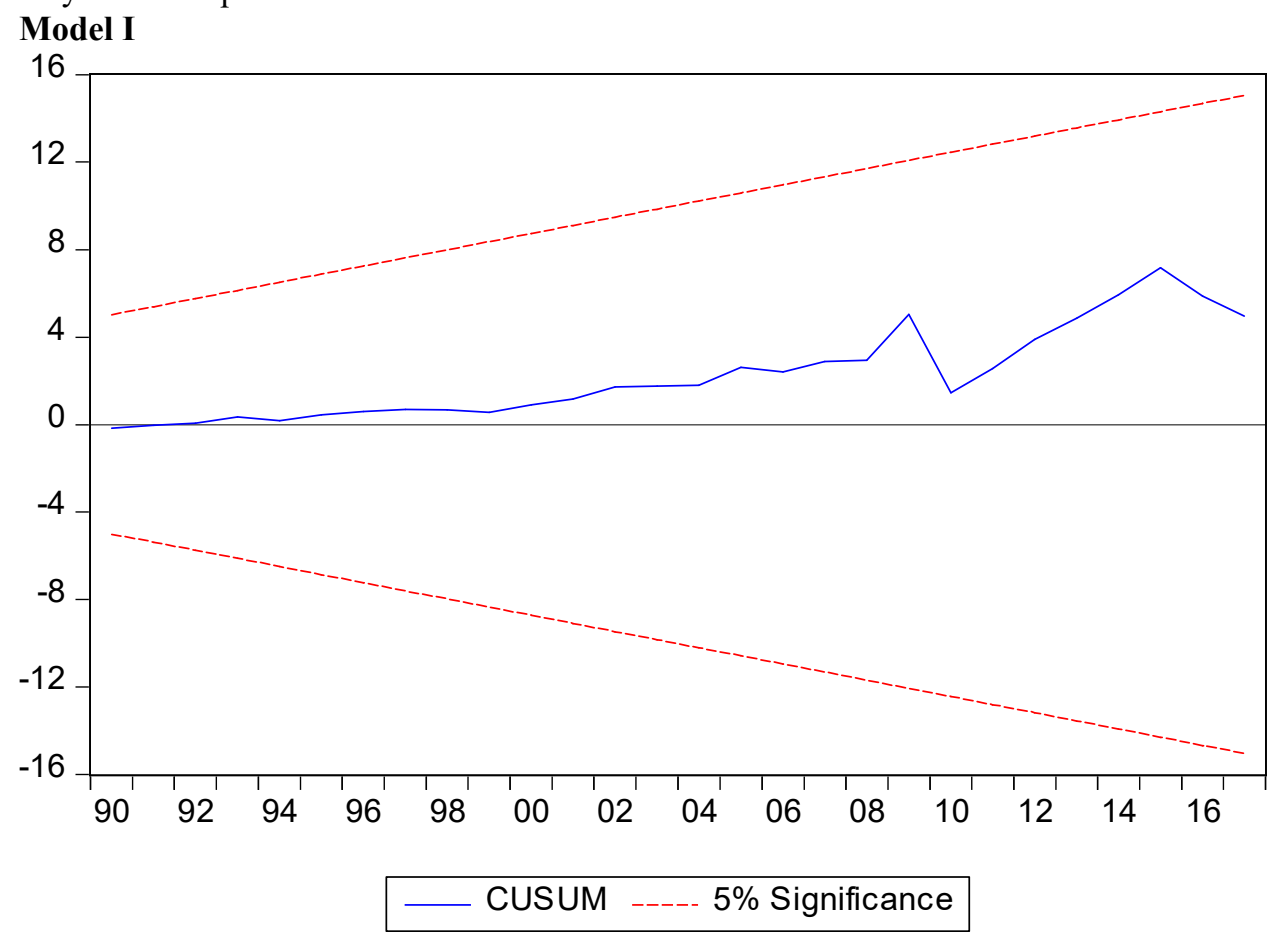




\section{Model II}

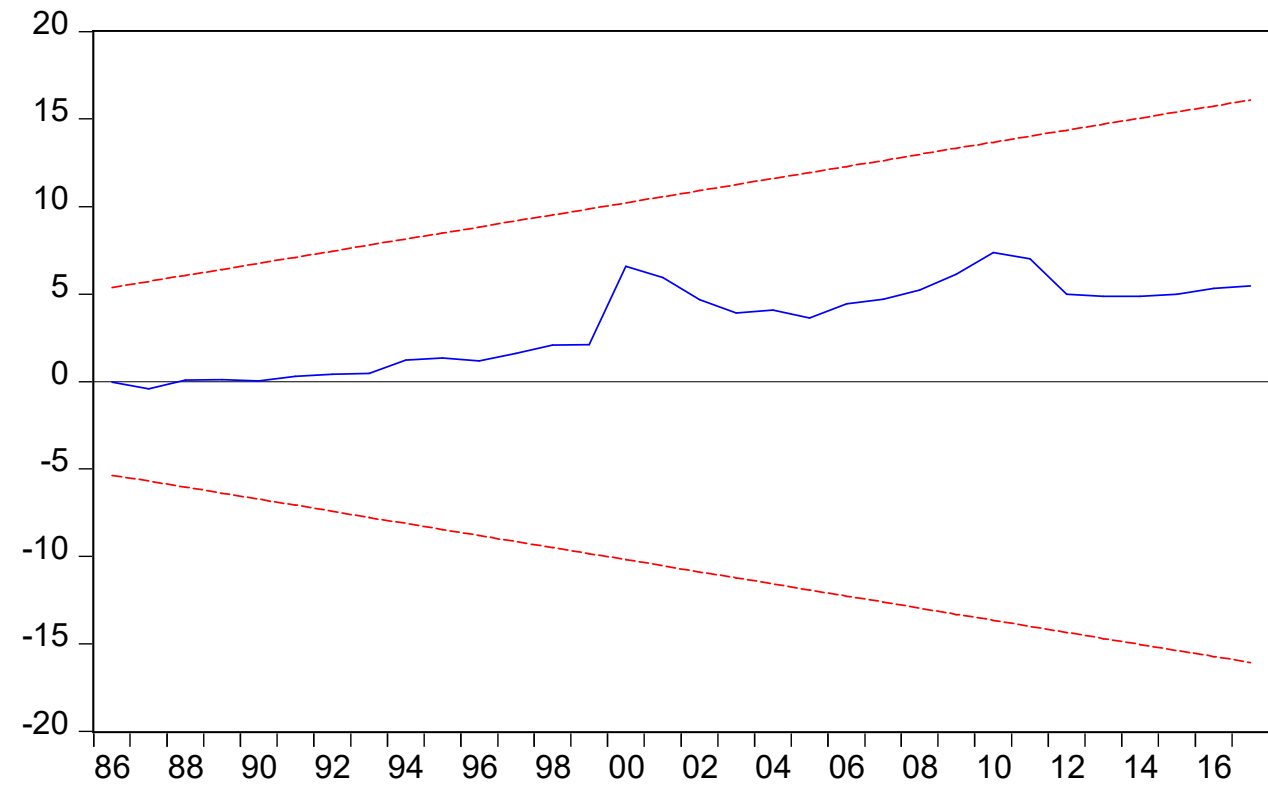

\section{CUSUM ----- 5\% Significance}

\subsection{Granger Causality Tests}

Knowing the direction of cause between two variables is the main purpose of this test. It helps researchers determine, among others, the direction of cause between a dependent variable and other independent variables. This direction of cause can take the form of unidirectional causality or bidirectional causality. Below, the analysis shows that in model $\mathrm{I}$, there are almost bidirectional causality between the dependent and all the independent variables: GDP granger causes GEEH, GEDU and GAGR and vice versa.

In model II shows that there is a unidirectional causality between GEEH, GEDU and GAGR with UNEM. It shows that UNEM granger causes GEEH, GEEH while GAGR granger causes UNEM.

\section{Model I}

Pairwise Granger Causality Tests

Date: 12/04/19 Time: 15:27

Sample: 19802017

Lags: 2

\begin{tabular}{lccr}
\hline \hline Null Hypothesis: & Obs & F-Statistic & Prob. \\
\hline \hline GAGR does not Granger Cause GDP & \multirow{2}{*}{36} & 3.12624 & 0.0580 \\
GDP does not Granger Cause GAGR & & 1.95948 & 0.1580 \\
\hline \hline GEDU does not Granger Cause GDP & \multirow{2}{*}{36} & 15.5503 & 2. E- 05 \\
GDP does not Granger Cause GEDU & & 4.84025 & 0.0148 \\
\hline \hline GEEH does not Granger Cause GDP & \multirow{2}{*}{36} & 1.80874 & 0.1807 \\
GDP does not Granger Cause GEEH & & 2.06529 & 0.1439
\end{tabular}

Source: Eviews 


\section{Model II}

Pairwise Granger Causality Tests

Date: 12/04/19 Time: 15:26

Sample: 19802017

Lags: 1

\begin{tabular}{lccr}
\hline \hline Null Hypothesis: & Obs & F-Statistic & Prob. \\
\hline \hline GEEH does not Granger Cause UNEM & 37 & 0.65132 & 0.4253 \\
UNEM does not Granger Cause GEEH & & 2.90748 & 0.0973 \\
\hline \hline GEDU does not Granger Cause UNEM & 37 & 0.07810 & 0.7816 \\
UNEM does not Granger Cause GEDU & & 4.25650 & 0.0468 \\
\hline \hline GAGR does not Granger Cause UNEM & 37 & 8.61817 & 0.0059 \\
UNEM does not Granger Cause GAGR & & 0.18138 & 0.6729 \\
\hline \hline SOurC: $=\bar{c}$
\end{tabular}

Source: Eviews

\subsection{Tests of hypotheses}

$\mathbf{H}_{01}$ : The short run analysis shows that there is a negative relationship between government's total expenditure on agriculture and the gross domestic products (GDP). This shows that as total expenditure on agriculture increases by a unit, gross domestic products decreases by -3562148 and vice versa. The result also shows that total expenditure on Agriculture is statistically insignificant using the 5\% level of significance. We therefore reject the alternative hypotheses, accept the null and conclude that there is no significant relationship between total government expenditure on agriculture and gross domestic products over the period.

Ho2: The result also shows that government expenditure on education has positive relationship with the gross domestic products. As government expenditure on education increases by a unit, gross domestic products increases by 53 units and vice versa. Government expenditures on education is also shown to be statistically significant based on the t-statistic. We therefore accept alternative hypothesis and conclude that there is a significant relationship between government expenditure on education and gross domestic products over the period.

$\mathbf{H}_{03}$ : The analysis reveals that government expenditure on health has a positive but insignificant relationship with gross domestic products. As government expenditures on health increases by a unit, GDP increases by 20009 units and vice versa. It is also significant at $5 \%$ level of significance. We will reject the null hypotheses, accept the alternative and conclude that there is a significant relationship between government expenditure on health and gross domestic products.

H04: For unemployment, the analysis shows that government expenditures on agriculture has negative and insignificant relationship with unemployment rate. As government expenditures on agriculture increases, the unemployment rate goes down by 0.026 units and vice versa. The government expenditures on agriculture is also statistically insignificant at 5\% level. We will accept the alternative hypotheses, reject the null and conclude that there is no significant relationship between government expenditures on agriculture and unemployment rate.

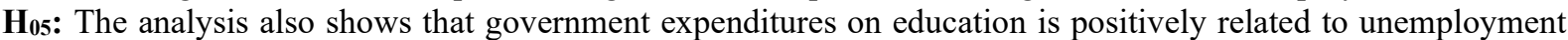
rate. An increase in government expenditures on education by a unit increases unemployment rate by 2.09 units. Government expenditure on education is not statistically significant at 5\%. Thus the null hypothesis is rejected while the alternative is accepted. We therefore conclude that there is a significant relationship between government expenditures on education and unemployment rate.

H06: The analysis shows that government expenditures on health is also positively related to unemployment rate, but statistically insignificant. A unit increase in government expenditures on health results in a 1.5units increase in the unemployment rate. This is not expected apriori. Government expenditures on health is statistically insignificant at 5\% level. We will therefore, reject the null, accept the alternative and conclude that there is a significant relationship between government expenditures on health and unemployment rate over the period.

\subsection{Discussion of findings}

The analyses have revealed that government's expenditure on agriculture has negative relationship with gross domestic products and unemployment rate. Both models show that more government expenditure in the agricultural sector will negatively affect the economy. This agrees with the findings of Shengyam Fam and Nectan Raw (2003) and Junko and Vitali, (2008) who maintain that the government has no business in running business such as the agricultural sector. This, being a major sector, should be left for the private sector to properly manage as it should be. 
Again, the study shows that total government's expenditure on education positively affects gross domestic products and unemployment rate. However, the expectation is that government spending on education should have a negative relationship with unemployment. The findings disagree with the previous findings where government expenditures on education is expected to aid in reducing the rate of unemployment in the country. Unfortunately, the findings show that government expenditures on health have the impact of increasing the incidences of unemployment over the period. The findings are not in-line with the Keynesian theory of employment as well as the classical theories of employment.

\subsection{Conclusion and Recommendations}

The study, which focused on the impact of government expenditures on macroeconomic variables, used the gross domestic products (GDP) and unemployment rate (UNEM) to capture the macroeconomic variables used in this study, while government expenditures on agriculture, education and health were used to capture government expenditure on key sectors of the economy. The researchers found that in general, governments expenditure on agriculture does not exactly impact on economic development using the gross domestic products and unemployment rate. However, the other expenditures were found to have negative and insignificant effects on the dependent variables used.

Based on the outcome of this research, it is therefore, recommended that governments direct financial expenditures on agriculture should be reduced gradually until it is eliminated. As found out from the study, there is no significant relationship between the expenditure and economic growth or employment. Thus, the private sector must be encouraged to take up this responsibility and grow the economy faster than the government can.

The governments' expenditures on health and education do not significantly affect GDP although, they have positive impact. The expenditures must be increased if the impact must be felt.

Finally, the unemployment rate was shown to have positive relationship with the government expenditures on health and education. They were supposed to have negative relationships however. This could be a pointer to the fact that there is something fundamentally wrong with our educational system: out-dated curriculum that makes the graduates unemployable, etc. Therefore, the researcher recommends that the government sustains their expenditures in these sectors but must work on the root causes of what happens in the educational system of the country.

\section{References}

Abbas, Q., Akbar, S., Nasir, A. S., Ullah, H. A., \& Naseem, M. A. (2011). Impact of foreign direct investment on gross domestic product. Global Journal of Management and, Business Research, 11 (8), 1-7.

Akpan NI (2005). Government expenditure and economic growth in Nigeria: A disaggregated approach. CBN Econ. Financ. Rev.43(1):51-69

Ando, S. (2009). "The Impact of Defense Expenditure on Economic Growth: Panel Data Analysis Based on the Feder Model”. The International Journal of Economic Policy Studies, Vol. 4: 141 - 154.

Anyanwu, J.C. (1997). Nigerian public finance. Onitsha: Joanee Educational Publishers Ltd. International Journal of Economic Development Research and Investment, Vol. 1(2 \& 3): 37-46.

Appah, E. (2010). "The Relationship Between Fiscal Policy and Economic Growth in Nigeria: 1991-2005". International Journal of Economic Development Research and Investment, Vol. 1(2 \& 3): 37-46.

Aricò, F.R. (2003). Growth and unemployment: Towards a theoretical integration. Journal of Economic Surveys, 17 (3), 419-455.

Arpaia, A. and Turrini, A. (2008). "Government Expenditure and Economic Growth in the EU: Long-Run tendencies and Short-Term Adjustment”, European Commission.

Ayanwale, A. B. (2007). FDI and economic growth: Evidence from Nigeria. AERC Research Paper 163. African Economic Research Consortium, Nairobi.

Bagdigen, M. and Cetintas, H. (2004). "Causality between Public Expenditure and Economic Growth: The Turkish Case". Journal of Economic and Social Research, Vol. 6(1): 53 - 72.

Bose, N. Haque, M. E. and Osborn, D. R. (2007). Public Expenditure and Economic Growth: A Disaggregated Analysis for Developing Countries, The Manchester School, vol. 75, no.5, pp.533-556.

Canning, D. and Pedroni, P. (2004). "The Effect of Infrastructure on Long Run Economic Growth". Retrieved on 13/8/2010 from www.williams.edu/Economics/wp/pedroniinfrastructure.pdf

Central Bank of Nigeria (2017). CBN Annual Report and Statistical Bulletin for the year Ended 31st December 2017.

Colombier, C. (2009). "Does the Composition of Public Expenditure Impact Economic Growth? Evidence from Switzerland Using a Robust Cointegration Approach". Retrieved on 21/8/202 from www.boeckler.de/pdf/v_2009_10_colombier.pdf

Ekweogu, R. N. (2013). The impact of foreign direct investment on economic growth in Nigeria. An unpublished B.Sc. project, department of economics, Faculty of management and social sciences, Caritas University, 
Amorji - Nike, Enugu State. en.wikipedia.org/wiki, (2015).

International Labour Organization (1982). Resolutions concerning statistics of the economically active population and underemployment, adopted by the $13^{\text {th }}$ international conference of labour statisticians.

International Labour Organization, (2010). Global employment trends for youths on the impact of the global economic crisis on youths. Geneva. ILO.

Josten, S.D. (2006). Dynamic fiscal policies and unemployment in a simple endogenous growth model. International Tax and Public Finance, 13 (6), 701-716.

Keynes JM (1936). The general theory of employment, interest and money. New York: Harcourt, Brace and co.

Lecuwen, B. V. and Foldvari, P. (2007). "Human Capital and Economic Growth in Asia 1890-2000: A Time Series Analysis". Retrieved on $21 / 8 / 2010$ from www.basvanleeuwen.net/bestanden/human_capital_growth_asia.pdf

Maku, O.E. (2009). "Does Government Spending Spur Economic Growth in Nigeria? Munich Personal RePEc Archive. Retrieved on 13/8/2010 from http://mpra.ub.uni-muenchen.de/17941/MPRA Paper no. 17941.

Moreno-Galbis E. (2012). The impact of TFP growth on the unemployment rate: Does on-the-job training matter? CEPREMAP Working Papers (Docweb), No. 1207.

Musgrave RA (1969). Fiscal systems. New Haven and London: Yale University Press.

Musgrave, R.A., and Musgrave, P. B. (1989). The Theory of Public Finance. New York: McGraw-Hill.

National Directorate of Employment (NDE) (2013). NDE Annual Report. Abuja: A1-Donas Avia Tech. Nig. Ltd.

Neto, A., \& Silva, S.T. (2013). Growth and unemployment: A bibliometric analysis on mechanisms and methods. FEP Working Papers Faculdade de Economia da Universidade do Porto, No. 498.

Newsweek Report on Unemployment (2011). Obtained from www.newsweek.com.ng.

Okodua, H. (2009). Foreign direct investment and economic growth: Co-integration and causality analysis of Nigeria. The African Finance Journal, 11 (1), 54-73.

Olayiwola, K., \& Okodua, H. (2007). Foreign direct investment, non-oil exports, and economic growth in Nigeria: A causality analysis.JEL classification: C33, C32, F43, F21

Omankhanlen, A.E. (2011). Foreign direct investment and its effect on the Nigerian economy. Business Intelligence Journal, Vol. 4, No.2.

Oyinlola, M.A. and Akinnibosun, O. (2013). "Public expenditure and economic growth nexus: Further evidence from Nigeria", Journal of Economics and International Finance, 5(4). Pp. 146-154.

Parello, C. P. (2010). A schumpeterian growth model with equilibrium unemployment. Metroeconomica, 61 (2), 398-426.

Peacock, A. T., \& Wiseman, J. A. (1961). The Growth of Public Expenditure in the United Kingdom. Priceton: George Allen Union Limited.

Pissarides, C. A. (2000). Equilibrium unemployment theory. The MIT Press, Cambridge, Massachusetts - London, England.

Salami, C.G.E. (2013). Youth unemployment in Nigeria: A time for creative intervention. International Journal of Business and Marketing Management, 1 (2), 18-26. www.resjournals.org/IJBMM.

Todaro, M.P and Smith, S.C. (2006), "Economic Development" Pearson Education Ltd. Edinburgh Gate Harlow, Essex, UK.

Tripier, F. (2007). The long run relationship between growth and unemployment. A Transatlantic Perspective."Mimeo".

Wagner A (1883). Three extracts on public finance, in Musgrave R.A. and Peacock A.T. (eds) (1958), Classics in the Theory of Public Finance. London: Macmillan.

Yasin, M. (2008). "Public Spending and Economic Growth: Empirical Investigation of Sub-Saharan Africa". Southwestern Economic Review: 59-68. Retrieved on 21/8/2010 fromwww.ser.tcu.edu/2003/SER2003\%20Yasin\%2059.68.pdf

Yuk, W. (2005). "Government Size and Economic Growth: Time Series Evidence for the United Kingdom, 1830 to 1993". Econometrics Working Paper EWP0501, University of Victoria. Retrieved on 21/8/2010 from http://web.uvic.ca/econ/research/papers/ewp0501.pdf 